Jurnal Ilmu-Ilmu Peternakan 26 (1): 7 - 15

ISSN: 0852-3681

E-ISSN: 2443-0765

CFakultas Peternakan UB, http://jiip.ub.ac.id/

\title{
Pengaruh penggantian Bovine Serum Albumin (BSA) dengan putih telur pada pengencer CEP-2 terhadap kualitas semen sapi Peranakan Ongole pada suhu penyimpanan $3-5^{\circ} \mathrm{C}$
}

\author{
Nisa'us Sholikah, Nurul Isnaini, Aulia Puspita Anugra Yekti, Trinil Susilawati \\ Fakultas Peternakan, Universitas Brawijaya, Malang \\ Jl. Veteran Malang 65145 Jawa Timur \\ trinil_susilawati@yahoo.com
}

\begin{abstract}
Purpose of this research was to investigate the effect of Bovine Serum Albumin substitution by albumen on CEP-2 to semen quality Ongole CrossBred bull stored at $3-5^{\circ} \mathrm{C}$. Research was conducted at Research Centre Beef Cattle Laboratory, Grati, Pasuruan on February 2016. Semen diluent was divided into two groups, there were P0 (90\% CEP-2 + 10\% Egg Yolk (EY)); and P1 (90\% CEP + 0.4\% albumen + $10 \% \mathrm{EY})$. Data of the research were analyzed using paired design $t$ test. The result showed that after eight days chilled preservation, percentage of motility P1 $(47.4 \pm 10.9 \%)$ was higher than P0 $(47 \pm 9.2 \%)$. Percentage of viability P0 $(83.1 \pm 1.9 \%)$ was higher than P1 $(81.3 \pm 1.5 \%)$. Percentage of abnormality P1 $(3.6 \pm 0.4 \%)$ was lower than P0 $(3.8 \pm 0.3 \%)$. Total motile sperm count after six days chilled preservation was significantly higher in all treatments compared to the standard criteria of SNI $40 \%$ motile sperm $/ \mathrm{ml}$. The conclusion of this research was $0,4 \%$ albumen could replace the BSA capability on CEP-2.
\end{abstract}

Keywords: CEP-2, Bovine Serum Albumin, chilled preservation, semen quality

\section{PENDAHULUAN}

Sapi Peranakan Ongole (PO) merupakan salah satu plasma nutfah asli Indonesia yang memiliki produktivitas cukup baik. Peningkatan produktivitas sapi PO dapat dipercepat dengan penerapan berbagai teknologi di bidang peternakan mulai dari teknologi pakan hingga teknologi reproduksi. Khusus untuk teknologi reproduksi, pada saat ini, inseminasi buatan (IB) merupakan teknologi yang tepat untuk diterapkan pada peternakan. Inseminasi buatan merupakan teknologi yang dapat mengatasi keterbatasan jumlah pejantan unggul, serta kapasitas reproduksi pejantan dapat dimanfaatkan secara maksimal (Rizal, 2009). Teknologi IB menggunakan semen beku telah dikenal di seluruh Indonesia. Permasalahan dalam penanganan semen beku yang sering dijumpai di lapang adalah kesulitan dan keterlambatan dalam memperoleh nitrogen cair dan keterbatasan kontainer di lapang (Pratiwi dkk., 2005) meskipun Nitrogen cair tersedia di semua daerah. Selain itu, Susilawati (2013) menjelaskan bahwa spermatozoa setelah mengalami pembekuan dan thawing banyak yang mengalami kerusakan membran. Salah satu cara untuk mengatasi masalah tersebut adalah dengan menggunakan semen cair (liquid semen). 
Kondisi spermatozoa yang mudah mengalami kerusakan pada saat perlakuan maupun penyimpanan, membutuhkan pengencer yang dapat mempertahankan kualitas selama penyimpanan (Susilawati, 2013). Beberapa jenis pengencer seperti Tris Aminomethane dan Andromed telah terbukti mampu mempertahankan kualitas semen selama pendinginan. Pengencer yang sedang dalam tahap perkembangan adalah pengencer Cauda Epididymal Plasma 2 (CEP-2) yang memiliki komposisi kimia seperti $\mathrm{NaCl}$, $\mathrm{KCL}, \mathrm{CaCl}_{2}\left(\mathrm{H}_{2} \mathrm{O}\right)_{6}, \mathrm{NaH}_{2} \mathrm{PO}_{4}, \mathrm{KH}_{2} \mathrm{PO}_{4}$, fruktosa, sorbitol, Bovine Serum Albumin (BSA), tris, gentamicin dan asam sitrat (Verberckmoes et al., 2004).

Bovine Serum Albumin (BSA) merupakan salah satu bahan dalam pengencer CEP-2 yang merupakan produk impor dengan harga yang sangat mahal dan sulit didapatkan, sehingga untuk mengatasi kendala tersebut dibutuhkan penelitian untuk memperoleh bahan pengencer pengganti yang dapat diperoleh secara mudah, murah, serta memiliki kualitas yang baik. Salah satu alternatif yang bisa digunakan untuk mengganti BSA pada pengencer CEP-2 adalah putih telur. Soekarta (2013) menyatakan bahwa putih telur mengandung 18 asam amino yaitu alanin, arginin, asam aspartik, asam glutamat, cystin, glysin, histidin, iso leucin, leucin, lysine, methionin, fheny alanin, prolin, serin, theoronin, trypthofhan, tryosin, dan valin. Kandungan asam amino dan albumin pada putih telur diharapkan dapat membantu mempertahankan kondisi spermatozoa. Berdasarkan fakta tersebut, maka penelitian ini bertujuan untuk mengetahui pengaruh penggantian BSA pada pengencer CEP2 menggunakan putih telur terhadap motilitas, viabilitas dan abnormalitas semen sapi PO selama penyimpanan pada suhu $3-5^{\circ} \mathrm{C}$.

\section{MATERI DAN METODE}

Penelitian dilaksanakan pada tanggal 1 Februari 2016 sampai tanggal 29 Februari 2016 di Laboratorium Reproduksi Loka Penelitian Sapi Potong Grati, Pasuruan. Materi penelitian yaitu semen segar sapi Peranakan Ongole (PO) dari Loka Penelitian Sapi Potong Grati, Pasuruan. Persyaratan semen segar yang digunakan yaitu semen yang mempunyai motilitas individu $\geq 70 \%$ dan motilitas massa 2+. Kuning telur (KT) yang digunakan berasal dari telur segar ayam ras petelur (layer) dengan umur telur <3 hari. Bahan tambahan pengencer yang digunakan untuk mengganti BSA yaitu albumin yang diambil dari telur segar bagian thin albumin.

Metode penelitian yang digunakan adalah metode eksperimen laboratorium dengan 2 perlakuan dan 10 ulangan. Perlakuan penelitian yaitu P0 $(90 \%$ CEP-2 + $10 \% \mathrm{KT})$ dan P1 $(90 \%$ $\mathrm{CEP}+0,4 \%$ putih telur $+10 \% \mathrm{KT})$. Variabel penelitian yang diamati yaitu variabel bebas berupa pengencer dan variabel tidak bebas meliputi: persentase motilitas individu, persentase viabilitas, persentase abnormalitas, dan total spermatozoa motil. Data dianalisis dengan statistik deskriptif dan diuji lebih lanjut menggunakan uji $t$ berpasangan. Pada hari yang terdekat dengan motilitas $40 \%$ dan total spermatozoa yang motil antara P0 dan P1 kemudian diuji menggunakan Pearson's Chi Square dengan nilai harapan 40\% sesuai dengan SNI.

\section{HASIL DAN PEMBAHASAN}

Pemeriksaan semen segar dilakukan secara langsung setelah penampungan semen. Kualitas semen 
segar dapat diketahui melalui dua cara yaitu pemeriksaan secara makroskopis dan mikroskopis. Pemeriksaan makroskopis meliputi volume, warna, bau, konsistensi, dan $\mathrm{pH}$. Pemeriksaan mikroskopis meliputi motilitas massa, motilitas individu (\%), dan konsentrasi. Hasil pemeriksaan kualitas semen segar secara makroskopis dan mikroskopis dapat dilihat pada Tabel 1.

Tabel 1. Hasil rataan pemeriksaan semen segar sapi PO

\begin{tabular}{ll}
\hline Parameter & Rataan \pm SD \\
\hline Makroskopis & \\
Volume (ml) & $5,9 \pm 1,9$ \\
Warna & Putih kekuningan \\
Bau & Khas semen \\
pH & $7 \pm 0$ \\
Konsistensi & Sedang \\
\hline Mikroskopis & \\
Motilitas Massa & $2+$ \\
Motilitas Individu (\%) & $70 \pm 0$ \\
Konsentrasi (juta/ml) & $1177,1 \pm 450,2$ \\
\hline
\end{tabular}

Volume semen masih dalam kategori normal sesuai pendapat Garner and Hafez (2008) yang menyatakan volume semen sapi setiap penampungan bervariasi dengan kisaran 1-15 $\mathrm{ml}$ atau 5-8 ml per ejakulasi. Semen sapi PO yang digunakan pada penelitian mempunyai warna putih kekuningan sehingga bisa dikategorikan berkualitas baik. Susilawati (2013) menyatakan warna semen sapi yang normal adalah putih susu atau putih kekuningan disebabkan karena terdapat riboflavin, sedangkan semen yang abnormal berwarna kuning kemerahan karena adanya air, nanah dan darah. Semua semen segar yang diperoleh pada penelitian mempunyai bau khas sapi. Rataan $\mathrm{pH}$ semen segar yang diperoleh $7 \pm 0$, hal ini sesuai pendapat Garner and Hafez (2008) yang menyatakan kisaran normal $\mathrm{pH}$ semen sapi adalah 6,4-7,8. Konsistensi semen segar dalam kategori sedang. Susilawati (2013) menjelaskan bahwa konsistensi semen sedang mengandung $\quad 1000.10^{6}-1500.10^{6}$ spermatozoa $/ \mathrm{ml}$ semen.

Hasil pemeriksaan secara mikroskopis mendapatkan hasil motilitas massa 2+, motilitas individu sebesar $70 \pm 0 \%$ dan konsentrasi sebesar 1177,1 $\pm 450,2 \quad$ juta/ml. Hasil pemeriksaan mikroskopis menunjukkan bahwa semen segar layak proses sesuai dengan pendapat Michael et al.(2010) yang menyatakan bahwa persentase motilitas individu semen segar yang akan diproses memiliki standar minimal sebesar $65 \%$.

\section{Persentase motilitas spermatozoa selama penyimpanan suhu $3-5^{\circ} \mathrm{C}$}

Persentase motilitas spermatozoa diamati setiap 24 jam sekali dimulai pada hari pertama penyimpanan hingga persentase motilitas turun menjadi 30\% yaitu hari ke-8. Persentase motilitas individu spermatozoa dinilai dengan menghitung persentase spermatozoa yang bergerak progresif ke depan.

Rataan persentase motilitas spermatozoa disajikan pada Tabel 2 dimana P1 (90\% CEP (tanpa BSA) + $0,4 \%$ putih telur $+10 \% \mathrm{KT}$ ) lebih tinggi dari pada rataan persentase motilitas spermatozoa pada P0 (90\% CEP-2 + $10 \% \mathrm{KT})$. 
Tabel 2. Rataan persentase motilitas spermatozoa

\begin{tabular}{ccc}
\hline \multirow{2}{*}{ Perlakuan/Waktu } & \multicolumn{2}{c}{ Motilitas (\%) } \\
\cline { 2 - 3 } & $63,5 \pm 4,1$ & P1 \\
\hline Hari 1 & $53,5 \pm 4,7$ & $63,0 \pm 3,5$ \\
Hari 2 $^{* *}$ & $50,5 \pm 10,9$ & $58,0 \pm 5,4$ \\
Hari 3 $^{* *}$ & $48,5 \pm 10,8$ & $52,5 \pm 8,6$ \\
Hari 4 $^{* *}$ & $45,0 \pm 10,0$ & $50,5 \pm 8,6$ \\
Hari 5 $^{*}$ & $41,5 \pm 6,7$ & $47,5 \pm 9,5$ \\
Hari 6 & $39,5 \pm 5,0$ & $41,0 \pm 8,8$ \\
Hari 7** & $34,0 \pm 4,6$ & $35,5 \pm 5,5$ \\
Hari 8 & & $31,0 \pm 4,6$ \\
\hline
\end{tabular}

Keterangan:

P0 : 90\% CEP-2 + 10\% KT

P1 : 90\% CEP (tanpa BSA) $+0,4 \%$ putih telur $+10 \% \mathrm{KT}$

* : terdapat perbedaan nyata antara $\mathrm{P} 0$ dan $\mathrm{P} 1(\mathrm{P}<0,05)$

** : terdapat perbedaan sangat nyata antara $\mathrm{P} 0$ dan $\mathrm{P} 1(\mathrm{P}<0,01)$

Berdasarkan Tabel 2, rataan persentase motilitas spermatozoa selama penelitian menunjukkan bahwa penggunaan pengencer $\mathrm{P} 0$ (90\% CEP-2 $+10 \%$ KT) maupun P1 (90\% CEP $($ tanpa BSA $)+0,4 \%$ putih telur $+10 \%$ KT) selama penyimpanan dingin hingga hari ke-6 masih diatas standar untuk dapat digunakan inseminasi buatan (IB) yaitu secara berturut-turut sebesar $41,5 \pm 6,7 \%$ dan $41 \pm 8,8 \%$. Akan tetapi pada hari 6 rataan persentase motilitas spermatozoa pada P1 mulai mengalami penurunan yang drastis, hal ini diduga karena terdapat perkembangan mikroorganisme didalam pengencer P1. Didalam putih telur yang digunakan untuk pembuatan pengencer terdiri dari berbagai macam komponen kimia sesuai pendapat Hui (2006) yang menyatakan bahwa didalam putih telur terdapat $88 \%$ air, $11 \%$ protein, serta karbohidrat, mineral, dan lemak dalam jumlah yang kecil. Kandungan air yang tinggi dan lamanya penyimpanan dapat menyebabkan tumbuhnya mikroorganisme sesuai dengan pernyataan Nugraha dkk. (2012) yang menjelaskan bahwa waktu penyimpanan telur juga mempengaruhi daya tahan telur dari cemaran.

Hasil analisis data uji $t$ berpasangan menunjukkan bahwa pada penyimpanan hari 1 tidak terdapat perbedaan nyata antara P0 dan P1 terhadap motilitas spermatozoa $(\mathrm{P}>0,05)$, akan tetapi pada hari selanjutnya terdapat perbedaan yang sangat nyata yaitu pada hari 2 , hari 3 , hari 4 , hari 6 , hari 7 , dan hari $8(\mathrm{P}<0,01)$, sedangkan terdapat perbedaan yang nyata pada hari $5(\mathrm{P}<0,05)$.

Berdasarkan hal tersebut, substitusi BSA dengan putih telur mampu mempertahankan motilitas spermatozoa sampai hari 5, sedangkan hari berikutnya putih telur cukup mampu mendekati kemampuan BSA dalam pengencer CEP-2. Hal ini sesuai dengan pendapat Sianturi dkk (2004) yang menyatakan putih telur dari telur ayam dapat digunakan sebagai albumin alternatif pengganti BSA (Bovine Serum Albumin) dalam proses pemisahan spermatozoa dan dianggap cukup layak untuk digunakan. Malik et al., (2015) menjelaskan bahwa semakin lama semen disimpan pada suhu dingin, maka 
spermatozoa kehilangan potensi motilitas progresif.

Persentase viabilitas spermatozoa selama penyimpanan suhu $3-5^{\circ} \mathrm{C}$

Viabilitas atau daya hidup spermatozoa dapat diamati melalui perubahan warna spermatozoa setelah diulas menggunakan pewarna eosin negrosin. Spermatozoa yang hidup ditandai dengan warna yang masih terang atau tidak menyerap warna karena membran sel spermatozoa dalam keadaan baik sedangkan spermatozoa mati akan menyerap warna akibat rusaknya membran sel spermatozoa. Hasil ulasan diamati menggunakan mikroskop perbesaran 400x.

Hasil penelitian menunjukkan rataan persentase viabilitas spermatozoa pada P0 (90\% CEP-2 + 10\% KT) lebih tinggi dari pada rataan persentase viabilitas spermatozoa pada P1 $(90 \%$ CEP (tanpa BSA) $+0,4 \%$ putih telur + $10 \%$ KT). Rataan persentase viabilitas spermatozoa ditampilkan pada Tabel 3.

Tabel 3. Rataan persentase viabilitas spermatozoa

\begin{tabular}{ccc}
\hline \multirow{2}{*}{ Perlakuan/Waktu } & \multicolumn{2}{c}{ Viabilitas $(\%)$} \\
\cline { 2 - 3 } & P0 & P1 \\
\hline Hari 1 & $85,5 \pm 4,1$ & $84,5 \pm 4,0$ \\
Hari 2 $^{* *}$ & $85,0 \pm 5,0$ & $82,7 \pm 5,7$ \\
Hari 3 $^{* *}$ & $84,7 \pm 4,8$ & $81,9 \pm 4,7$ \\
Hari 4 $^{* *}$ & $83,0 \pm 5,4$ & $80,8 \pm 2,6$ \\
Hari 5 $^{*}$ & $82,9 \pm 4,0$ & $80,8 \pm 2,2$ \\
Hari 6 & $82,6 \pm 4,2$ & $81,8 \pm 5,8$ \\
Hari 7** & $80,6 \pm 6,7$ & $79,6 \pm 6,4$ \\
Hari $8^{* *}$ & $80,5 \pm 3,1$ & $79,8 \pm 2,3$ \\
\hline
\end{tabular}

Keterangan:

P0 : $90 \%$ CEP-2 + 10\% KT

P1 : 90\% CEP (tanpa BSA) $+0,4 \%$ putih telur $+10 \% \mathrm{KT}$

* : terdapat perbedaan nyata antara $\mathrm{P} 0$ dan $\mathrm{P} 1(\mathrm{P}<0,05)$

$* *$ : terdapat perbedaan sangat nyata antara $\mathrm{P} 0$ dan $\mathrm{P} 1(\mathrm{P}<0,01)$

Hasil analisis data uji $t$ berpasangan menunjukkan bahwa selama penyimpanan dingin terdapat perbedaan yang sangat nyata terhadap viabilitas spermatozoa yaitu pada hari 1 , hari 2 , hari 4 , hari 5 , hari 6 , hari 7 , dan hari $8 \quad(\mathrm{P}<0,01)$, sedangkan terdapat perbedaan yang nyata pada hari 3 $(\mathrm{P}<0,05)$. Putih telur cukup mampu menggantikan BSA untuk mempertahankan viabilitas spermatozoa karena memiliki rataan persentase viabilitas spermatozoa $\geq 70 \%$ sampai hari 8 selama penyimpanan dingin. Spinaci et al. (2015) melaporkan bahwa penurunan viabilitas spermatozoa pada saat suhu menurun diduga disebabkan oleh fosfolipid membran sel spermatozoa yang mengalami kerusakan permanen dan penurunan fungsi membran sel. Menurut Uysal and Bucak (2007), fungsi BSA dalam pengencer adalah untuk melindungi integritas membran spermatozoa dari keadaan lingkungan misalnya keadaan panas ataupun reaksi oksidatif. Ditambahkan oleh $\mathrm{Li}$ et al. (2008) bahwa komposisi dan konformasi dari BSA yaitu: satu molekul BSA mengandung 583 asam amino dalam 
rantai polipeptida tunggal dengan berat molekul sekitar $66.000 \mathrm{~g} / \mathrm{mol}^{2}$.

\section{Persentase abnormalitas spermatozoa selama penyimpanan suhu $3-5^{\circ} \mathrm{C}$}

Perhitungan abnormalitas spermatozoa dilakukan dengan membuat preparat ulas menggunakan pewarna eosin negrosin kemudian dilakukan pengamatan dengan mikroskop perbesaran 400x. Persentase abnormalitas spermatozoa selama penyimpanan pada suhu $3-5^{\circ} \mathrm{C}$ pada penelitian mengalami peningkatan. Semakin lama penyimpanan membran sel akan rusak yang berpengaruh terhadap metabolisme spermatozoa. Menurut Sarder (2004), keadaan membran sel spermatozoa yang tidak sempurna akan meningkatkan abnormalitas spermatozoa.

Rataan persentase abnormalitas spermatozoa pada P0 (90\% CEP-2 + $10 \% \mathrm{KT}$ ) lebih tinggi dari pada rataan persentase motilitas spermatozoa pada P1 $(90 \%$ CEP (tanpa BSA) + 0,4\% putih telur $+10 \% \mathrm{KT})$. Rataan persentase abnormalitas spermatozoa ditampilkan pada Tabel 4.

Tabel 4. Rataan persentase abnormalitas spermatozoa

\begin{tabular}{ccc}
\hline \multirow{2}{*}{ Perlakuan/Waktu } & \multicolumn{2}{c}{ Abnormalitas (\%) } \\
\cline { 2 - 3 } & \multicolumn{2}{c}{ P0 } \\
\hline Hari 1 $^{*}$ & $3,3 \pm 1,6$ & $3,4 \pm 2,1$ \\
Hari 2 $^{* *}$ & $3,5 \pm 0,8$ & $3,2 \pm 0,7$ \\
Hari 3 $^{* *}$ & $3,6 \pm 1,2$ & $3,2 \pm 1,0$ \\
Hari 4 $^{*}$ & $3,9 \pm 1,4$ & $3,3 \pm 1,0$ \\
Hari 5 $^{*}$ & $4,1 \pm 1,5$ & $3,5 \pm 1,0$ \\
Hari 6 $^{*}$ & $4,0 \pm 1,9$ & $3,7 \pm 0,3$ \\
Hari 7 $^{*}$ & $4,0 \pm 1,2$ & $4,2 \pm 0,5$ \\
Hari $^{* *}$ & $4,1 \pm 1,1$ & $4,0 \pm 0,5$ \\
\hline
\end{tabular}

Keterangan:

P0 : $90 \%$ CEP-2 + $10 \%$ KT

P1 : 90\% CEP (tanpa BSA) $+0,4 \%$ putih telur $+10 \% \mathrm{KT}$

$*$ : terdapat perbedaan nyata antara $\mathrm{P} 0$ dan $\mathrm{P} 1(\mathrm{P}<0,05)$

** : terdapat perbedaan sangat nyata antara $\mathrm{P} 0$ dan $\mathrm{P} 1(\mathrm{P}<0,01)$

Hasil analisis data uji $t$ berpasangan menunjukkan bahwa terdapat perbedaan yang nyata pada hari 1,5 dan $6 \quad(\mathrm{P}<0,05)$ serta terdapat perbedaan yang sangat nyata pada hari 2 , hari 3, hari 4, hari 7 , dan hari $8(\mathrm{P}<0,01)$. Putih telur mampu menggantikan BSA untuk mempertahankan spermatozoa normal sampai hari 6. Pada hari 7 dan 8 terjadi peningkatan persentase abnormalitas spermatozoa yang signifikan pada P1 (90\% CEP (tanpa $\mathrm{BSA})+0,4 \%$ putih telur $+10 \% \mathrm{KT})$, sedangkan pada P0 (90\% CEP-2 + 10\% KT) cenderung bertahan. Hal ini dapat dipengaruhi beberapa faktor antara lain prosesing semen, penyimpanan, dan kondisi fisiologis pengencer (Susilawati, 2013). Semen cair menggunakan pengencer P0 maupun P1 bisa diaplikasikan untuk inseminasi buatan (IB), karena mempunyai persentase abnormalitas yang rendah meskipun disimpan selama 8 hari pada suhu dingin. Ax et al. (2008) melaporkan bahwa spermatozoa dengan abnormalitas 
lebih dari $20 \%$ tidak dapat digunakan untuk IB.

\section{Total spermatozoa motil}

Total spermatozoa motil dapat dicari dengan mengalikan volume semen dengan konsentrasi kemudian dikalikan dengan persentase motilitas individu (Susilawati, 2013). Total spermatozoa motil perlu diketahui karena peluang terjadinya fertilisasi ditentukan oleh jumlah spermatozoa motil progresif yang ada dalam suatu ejakulat. Suatu ejakulat ataupun semen cair dan semen beku yang digunakan harus memiliki total spermatozoa motil yang optimal untuk terjadinya fertilisasi (Salim dkk., 2012).

Rataan total spermatozoa motil semen cair yang disimpan selama 6 hari menunjukkan P0 (90\% CEP-2 + 10\% KT) memiliki nilai lebih tinggi dari pada rataan persentase motilitas spermatozoa pada P1 (90\% CEP (tanpa BSA) + 0,4\% putih telur $+10 \% \mathrm{KT})$. Rataan total spermatozoa motil ditampilkan pada Tabel 5.

Tabel 5. Rataan total spermatozoa motil pada pendinginan hari 6

\begin{tabular}{cc}
\hline Perlakuan & Total spermatozoa motil $(\mathrm{Juta} / \mathrm{ml})$ \\
\hline P0 & $41,5 \pm 6,7$ \\
P1 & $41,0 \pm 8,8$ \\
\hline
\end{tabular}

Keterangan:

P0: $90 \%$ CEP-2 + 10\% KT

P1: $90 \%$ CEP (tanpa BSA) $+0,4 \%$ putih telur $+10 \%$ KT

Hasil analisis menggunakan Pearson's Chi Square pada hari 6 dengan nilai harapan 40 juta spermatozoa motil per 100 juta konsentrasi menunjukkan perbedaan yang sangat nyata $(\mathrm{P}<0,01)$, Chi Square hitung > Chi Square tabel 0,01. Semen cair menggunakan pengencer $\mathrm{P} 0$ maupun P1 pada penyimpanan hari 6 bisa diaplikasikan untuk inseminasi buatan (IB) karena menunjukkan hasil spermatozoa motil yang lebih tinggi dari standar yang ditetapkan oleh SNI yaitu $40 \%$ spermatozoa motil dari total konsentrasi (BSN, 2005).

\section{KESIMPULAN DAN SARAN}

Penggunaan putih telur mampu menggantikan BSA dalam pengencer CEP untuk semen yang disimpan pada suhu $3-5^{\circ} \mathrm{C}$ ditinjau dari persentase motilitas, persentase viabilitas, dan persentase abnormalitas spermatozoa. Saran untuk penelitian ini, perlakuan P1 dengan kandungan 0,4\% putih telur dapat menggantikan BSA dalam pengencer CEP-2 hingga hari 5. Semen segar yang diencerkan dengan 90\% CEP $+0,4 \%$ putih telur $+10 \%$ KT selama penyimpanan sampai hari 6 dapat diaplikasikan untuk inseminasi buatan (IB). Perlu adanya penelitian lebih lanjut untuk mengkaji mikroorganisme yang tumbuh dan berkembang dalam pengencer.

\section{DAFTAR PUSTAKA}

Ax, R., M. Dally, B. Didion, R. Lenz, C. Love, D. Varner, Hafez, and M. Bellin. 2008. Semen evaluation in reproduction in farm animal. $7^{\text {th }}$ edition. Edited by Hafez, E.S.E. Co. Director. Reproductive Health Kiawah Island. South Carolina. USA: 365-370.

BSN. 2005. Semen beku sapi. Badan Standarisasi Nasional. SNI 014869.1-2005. BSN. Jakarta. 
Garner, D. L. and E. S. E Hafez. 2008. Spermatozoa and seminal plasma in reproduction in farm animals $7^{\text {th }}$ edition. Blackwell Publishing Professional. USA. 7:96-109.

Hui, Y. H. 2006. Handbook of food science, technology, and engineering. CRC Press,Taylor and Francis Group. New York: 90-3.

Li, Y., J. Lee, J. Lal, L. An and Q. Huang. 2008. Effects of $\mathrm{pH}$ on the interactions and conformation of bovine serum albumin: comparison between chemical force microscopy and small-angle neutron scattering. J. Phys. Chem. 112(2008): 3797-3806.

Malik, A., M. Laily and M. I. Zakir. 2015. Effect of long term storage (iki terusane) of semen in liquid nitrogen on the viability, motility, and abnormality of frozen thawed Frisian Holstein spermatozoa. Asian Pasific Journal of Reproduction. 4(1): 22-25.

Michael, A. J., C. Alexopoulus, E. A. Pontiki, D. J. H. Litina, P. Saratsis, and H. N. Ververidis. 2010. Effect of n-acetyl-1cysteinsupplementation in semen extenders on semen quality and reactive oxygen species of chilled canine spermatozoa. Reprod Domest Anim. 45(2010): 201207.

Nugraha, A., I. B. N. Swacita, dan K. P. $\mathrm{G}$ Tono. 2012. Deteksi bakteri Salmonella spp dan pengujian kualitas telur ayam buras. Indonesia Medicus Veterinus. 1(3) : 320-329.

Pratiwi, W. C., L. Affandhy dan D. Pamungkas. 2005. Observasi kualitas spermatozoa pejantan Simmental dan PO dalam straw dingin setelah penyimpanan 7 hari pada suhu $5^{\circ} \mathrm{C}$. Disampaikan pada Seminar Nasional

Teknologi Peternakan dan Veteriner 2005.

Rizal, M. 2009. Daya hidup spermatozoa epididimis sapi Bali yang dipreservasi pada suhu $3-5^{\circ} \mathrm{C}$ dalam pengencer tris dengan konsentrasi laktosa yang berbeda. Jurnal Ilmu Ternak dan Veteriner. 14(2): 142-149.

Salim, M. A., T. Susilawati dan S. Wahyuningsih. 2012. Pengaruh metode thawing terhadap kualitas semen beku sapi Bali, sapi Madura dan sapi PO. Agripet. 12(2): 14-20.

Sarder, M. J. U. 2004. Morphological sperm abnormalities of different breeds of AI bull and its impact on conception rate of cows in AI programme. Bang. J. Vet. Med. 2(2): 129-135.

Sianturi, R. G., P. Situmorang, E. Triwulanningsih, T. Sugiarti dan D. A. Kusumaningrum. 2004. Pengaruh isobutil metilxantina (IMX) dan waktu pemisahan terhadap kualitas dan efektifitas pemisahan spermatozoa dengan metode kolom albumin telur. Jurnal Ilmu Ternak dan Veteriner. 9(4):246-251.

Soekarta, T. 2013. Teknologi penanganan dan pengolahan telur. Alfabeta. Bandung.

Spinaci, M., S. Perteghella, T. Clhapanidas, G. Galeati, D. Vigo, C. Tamanini, and D. Bucci. 2015. Storage of sexed boar spermatozoa: limits and perspectives. Theriogenology. 30(2005) :1-9.

Susilawati, T. 2013. Pedoman inseminasi buatan pada ternak. University of Brawijaya Press. Malang.

Uysal, O. and M. N. Bucak. 2007. Effect of oxidized gluthatione, bovine serum albumin, cystein and 
lycopene on the quality of frozenthawed ram semen. Acta Vet. BRNO. 76: 383-390.

Verberckmoes, S., A. Van Soom, J. Dewulf, I. De Pauw and A. de
Kruif. 2004. Storage of fresh bovine semen in diluent based on the ionic composition of cauda epididymal plasma. J. Reprod. Dom. Anim. 39 (6): 1-7. 